\title{
LATE-SEASON SURVEY OF BUMBLE BEES ALONG CANADIAN HIGHWAYS OF BRITISH COLUMBIA AND YUKON TERRITORIES
}

\author{
Timothy D. Hatten ${ }^{1,3}$, James P. Strange ${ }^{2}$, and Jill M. Maxwell ${ }^{1}$
}

\begin{abstract}
AвSTRACT.-Bumble bees are important pollinators of flowering plants, foraging and providing pollination services throughout the growing season. They are adapted to cool temperatures and are among the most important of all pollinators at high elevations and northern latitudes. Over the past several decades, multiple species of bumble bees have experienced declines in both geographic range and abundance in Europe and North America, while 4 species of the genus Bombus (Bombus) have suffered dramatic declines in the United States. Such declines are not as evident in Alaska, and the status of Bombus remains relatively unknown in the adjacent territories of Canada. To begin addressing this knowledge gap, we sampled the bumble bee fauna foraging on floral patches along 5 highways of Canada and southeastern Alaska in a short-term, one-time survey during late summer 2010. We observed 14 species and found Bombus assemblages to be structured by broad geographic features and ecoregions. The Bombus species B. (B.) occidentalis and B. (B.) terricola were relatively abundant in sample sites west and east of the Rocky Mountains, respectively, and B. (Pyrobombus) vagans, B. (Cullumanobombus) rufocinctus, and B. occidentalis were the most abundant species across all sites.
\end{abstract}

RESUMEN.-Los abejorros son polinizadores importantes de las plantas con flores, forrajeando y prestando servicios de polinización a lo largo de la temporada de crecimiento. Están adaptados a las temperaturas bajas y se encuentran entre los polinizadores más importantes en altas elevaciones y en latitudes norteñas. En las últimas décadas, múltiples especies de abejorros han experimentado declives tanto en su distribución geográfica como en su abundancia en Europa y América del Norte, mientras que 4 especies del género Bombus (Bombus) han sufrido una disminución dramática en los E.U.A. Estos descensos no son tan evidentes en Alaska, y el estatus de Bombus sigue siendo relativamente desconocido en los territorios adyacentes de Canadá. Para empezar a solucionar esta brecha de conocimiento, muestreamos la fauna de abejorros forrajeadores en parches de flores en un plazo corto, una sola vez a finales de verano de 2010, a lo largo de 5 carreteras de Canadá y al sureste de Alaska. Observamos 14 especies y encontramos ensambles de Bombus estructurados por amplias características y ecorregiones geográficas. La especie de Bombus B. (B.) occidentalis y B. (B.) terricola fueron relativamente abundantes en los sitios de muestreo al oeste y al este de las Montañas Rocosas, respectivamente, y B. (Pyrobombus) vagans, B. (Cullumanobombus) rufocinctus, y B. occidentalis fueron las especies más abundantes en todos los sitios.

Bumble bees (Bombus Latreille) are important pollinators of flowering plants in wild and managed ecosystems (Goulson et al. 2008). Unlike most bees, the social bumble bees forage throughout the growing season, providing pollination services to a diversity of plants. In temperate North America, bumble bees are reported to be the most ubiquitous and species-rich group of native social bees (Kearns and Thomson 2001, Goulson 2010). Bumble bees are uniquely adapted to foraging in cool temperatures due to their thermoregulatory abilities (i.e., endothermic), large body size, and heavy pile coat (Bishop and Armbruster 1999). These characteristics, combined with adaptations for pollen transport, place bumble bees among the most important of all pollinators in high elevations and northern latitudes (Kearns and Thomson 2001); but see Armbruster and Guinn (1989) for the importance of solitary bees in these environments.

Over the past several decades, multiple species of bumble bees have experienced declines in both geographic range and abundance in Europe and North America (Goulson et al. 2008, Cameron et al. 2011). Narrow climatic niche breadth, losses in floral and nesting habitat, pathogen epidemics, competition with exotic bee species, habitat fragmentation, and exposure to pesticides are among the factors suggested to be causing these declines (Thomson 2004, Goulson et al. 2008, Cameron et al. 2011). In the United States, populations of 4 bumble bee species-Bombus (Bombus)

\footnotetext{
${ }^{1}$ Invertebrate Ecology Inc., 610 N. Almon \# 140, Moscow, ID 83843.

${ }^{2}$ USDA-ARS Pollinating Insects Research Unit - Biology, Management, and Systematics, Utah State University, BNR 255, Logan, UT 84322-5310.

${ }^{3}$ E-mail: timhatten@invertebrateecology.com
} 
affinis, Bombus (Bombus) franklini, Bombus (Bombus) occidentalis, and Bombus (Bombus) terricola - have exhibited dramatic declines in recent years (Thorp and Shepherd 2005, Colla and Packer 2008, Cameron et al. 2011). The primary causal factor has been hypothesized to be infection by the facultative intracellular fungal pathogen Nosema bombi (Thorp and Shepherd 2005), but conclusive links have yet to be shown (Cordes et al. 2012).

Historically, B. occidentalis has been reported from southern Alberta, British Columbia, and much of the Yukon and Alaska. In contrast, the closely related $B$. terricola has been recorded from Alberta to Newfoundland and Nova Scotia (Milliron 1971). However, Colla and Ratti (2010) assert that the current status of B. (Bombus) species in western Canada is unclear due to a paucity of baseline data. To shed light on B. (Bombus) population trends, these authors compared bumble bee counts from bee diversity studies on berry crops from a 20 -year period (early 1980s to early 2000s) in the Frazer Valley of southwest British Columbia and detected a decline in relative abundance of $B$. occidentalis; e.g., from $>20 \%$ to $1 \%$ (Colla and Ratti 2010). In contrast, in a survey to assess the status of $B$. (Bombus) and infection rates by $N$. bombi of Alaska, Koch and Strange (2012) surveyed bumble bees along major transportation corridors of the state and found B. occidentalis to be relatively abundant, especially in the Alaska interior. For example, B. occidentalis was present in $70 \%$ of their sites (14 of 20) and, where found, it often comprised $>50 \%$ of the bumble bee community (Koch and Strange 2012). Interestingly, $N$. bombi infection was also detected with highest incidence in B. occidentalis at $44 \%$. Infections were detected in other bumble bee species as well, although the prevalence of the pathogen was not as high (Koch and Strange 2012).

Adjacent to Alaska in northern British Columbia and the Yukon Territory, the status of B. (Bombus) and other bee species remains unclear (Koch and Strange 2012). To begin addressing this knowledge gap, we sampled bumble bees in roadside habitats of highways in northern British Columbia and southern Yukon Territory. Linear habitats such as roadsides have been shown to provide important habitat for invertebrate pollinators including butterflies (Munguira and Thomas 1992, Ries et al. 2001, Saarinen et al. 2005) and bees (Lentini et al. 2011). Favorable environmental conditions, habitat for nesting sites, and floral resources can make roadsides attractive to pollinators (Armbruster and Guinn 1989). Roadsides are also easy to access, which facilitates bee sampling.

Based on the recent findings of Koch and Strange (2012), we hypothesize that B. occidentalis is still relatively common in Canada adjacent to Alaska. To explore this hypothesis, we sampled bumble bee communities and species relative abundance and distribution at sites along highways in British Columbia (BC), Yukon Territory (YT), Alberta (AB), and southeast Alaska (AK). An analysis and discussion of community composition and distribution patterns by ecological regions (e.g., Commission for Environmental Cooperation [CEC] Level III ecoregions) encompassing the highways is also provided.

\section{Methods}

From 22 August to 5 September 2010, we sampled the bumble bee fauna foraging on floral patches along 5 highways (i.e., roadside habitats) in Canada and Alaska: Highway 41, the Alaska-Canadian Highway (hereafter "ALCAN"), Haines Highway, Yellowhead Highway, and Highway 97. One site was also sampled along Highway 40 in $\mathrm{AB}$ southeast of the ALCAN (Fig. 1).

Sampling effort per highway was dependent on length of the highway, weather, time of day, and available sites. The direction of travel dictated the order in which sites were sampled: southeast to northwest along the ALCAN, a $1547-\mathrm{km}$ section from Ground Zero, the starting point of the ALCAN at Dawson Creek, BC $\left(55^{\circ} 45^{\prime} 30.36^{\prime \prime} \mathrm{N}, 120^{\circ} 13^{\prime} 43.09^{\prime \prime} \mathrm{W}\right)$, to Haines Junction, YT $\left(60^{\circ} 45^{\prime} 9.40^{\prime \prime} \mathrm{N}, 137^{\circ} 30^{\prime} 37.52^{\prime \prime} \mathrm{W}\right)$; north to south on Haines Highway, a 237-km highway from Haines Junction, YT, to Haines, AK $\left(59^{\circ} 14^{\prime} 5.14^{\prime \prime} \mathrm{N}, 135^{\circ} 26^{\prime} 33.93^{\prime \prime} \mathrm{W}\right)$; west to east on Yellowhead Highway, a 714-km section from Prince Rupert, BC $\left(54^{\circ} 17^{\prime} 39.68^{\prime \prime} \mathrm{N}, 130^{\circ}\right.$ $\left.21^{\prime} 13.39^{\prime \prime} \mathrm{W}\right)$, to Prince George, BC $\left(53^{\circ} 55^{\prime}\right.$ $1.89^{\prime \prime} \mathrm{N}, 122^{\circ} 44^{\prime} 58.31^{\prime \prime} \mathrm{W}$ ); and north to south on Highway 97, a distance of $787 \mathrm{~km}$ from Prince George, BC, to the U.S. border, with the last sample point adjacent to Okanagen Provincial Park, BC $\left(49^{\circ} 40^{\prime} 52.82^{\prime \prime} \mathrm{N}, 119^{\circ} 43^{\prime}\right.$ $3.57^{\prime \prime} \mathrm{W}$ ) between Greata and Summerland, BC. 


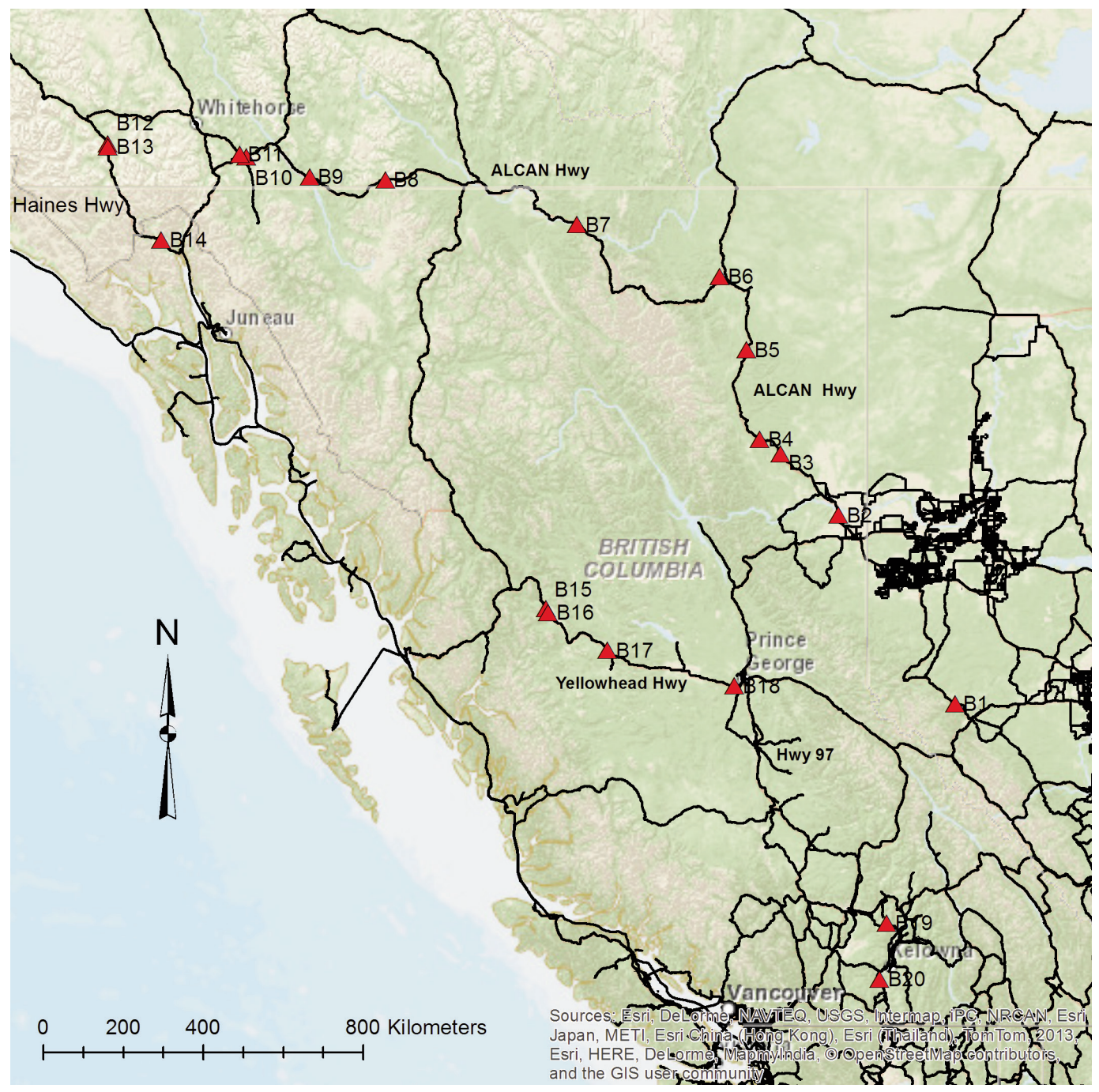

Fig. 1. Bumble bee sampling sites along the 5 sampled highways; Highway 41, Alaska-Canadian Highway, Haines Highway, Yellowhead Highway, and Highway 97. Sampling took place from 22 August to 5 September 2010.

A prerequisite to site sampling was to quickly inspect floral patches (generally one to several linear swaths of flowering plants $>20$ $m$ each in length) for activity of any kind of bees. If activity was observed, we sampled the site; if not we moved on to the next one. In this manner we surveyed approximately 100 sites throughout the study area, with approximately half found along the ALCAN and the remainder along the other highways. Bumble bees were detected and sampled in 20 (i.e., $20 \%$ ) of these sites; 12 were in BC, 6 in the YT, 1 in $A B$, and 1 in southeast $A K$.
The 20 sample sites in which we found Bombus were distributed across 8 CEC Level III ecoregions, with each ecoregion designated by a name or a 2-decimal-place code (or both), as follows: 2 within the Thompson-Okanagen Plateau (ER10.1.1), 2 within the Hay and Slave River Lowlands (ER3.3.2), 1 within the Mid-Boreal Uplands and Peace-Wabaska Lowlands (ER5.4.1), 3 within the Clear Hill and Western (AB) Uplands (ER5.4.2), 7 within the Watson Highlands (ER6.1.5), 1 within the Skeena-Omineca-Central Canadian Rocky Mountains (ER6.2.1), 3 within Chilcotin 
TABLE 1. Abundance and gender of bumble bee (Bombus) species captured in roadside sites.

\begin{tabular}{|c|c|c|c|c|c|c|c|c|}
\hline Site & Country & Province $^{\mathrm{a}}$ & Ecoregion $^{b}$ & Highwayc & Species & Male & Female & Total \\
\hline B1 & Canada & $\mathrm{AB}$ & 5.4 .2 & 40 & B. centralis & 3 & 0 & 3 \\
\hline B1 & Canada & $\mathrm{AB}$ & 5.4 .2 & 40 & B. flavifrons & 0 & 14 & 14 \\
\hline B1 & Canada & $\mathrm{AB}$ & 5.4 .2 & 40 & B. vagans & 5 & 1 & 6 \\
\hline B2 & Canada & $\mathrm{BC}$ & 5.4 .1 & ALCAN & B. rufocinctus & 7 & 13 & 20 \\
\hline B3 & Canada & $\mathrm{BC}$ & 5.4 .2 & ALCAN & B. flavifrons & 0 & 1 & 1 \\
\hline B3 & Canada & $\mathrm{BC}$ & 5.4 .2 & ALCAN & B. terricola & 0 & 1 & 1 \\
\hline B4 & Canada & $\mathrm{BC}$ & 5.4 .2 & ALCAN & B. flavifrons & 0 & 7 & 7 \\
\hline B4 & Canada & $\mathrm{BC}$ & 5.4 .2 & ALCAN & B. perplexus & 0 & 2 & 2 \\
\hline B4 & Canada & $\mathrm{BC}$ & 5.4 .2 & ALCAN & B. terricola & 1 & 6 & 7 \\
\hline B5 & Canada & $\mathrm{BC}$ & 3.3 .2 & ALCAN & B. moderatus & 4 & 0 & 4 \\
\hline B5 & Canada & $\mathrm{BC}$ & 3.3 .2 & ALCAN & B. rufocinctus & 0 & 1 & 1 \\
\hline B5 & Canada & $\mathrm{BC}$ & 3.3 .2 & ALCAN & B. suckleyi & 1 & 0 & 1 \\
\hline B5 & Canada & $\mathrm{BC}$ & 3.3 .2 & ALCAN & B. ternarius & 1 & 1 & 2 \\
\hline B5 & Canada & $\mathrm{BC}$ & 3.3 .2 & ALCAN & B. terricola & 5 & 0 & 5 \\
\hline B5 & Canada & $\mathrm{BC}$ & 3.3 .2 & ALCAN & B. vagans & 1 & 0 & 1 \\
\hline B6 & Canada & $\mathrm{BC}$ & 3.3 .2 & ALCAN & B. terricola & 1 & 0 & 1 \\
\hline B6 & Canada & $\mathrm{BC}$ & 3.3 .2 & ALCAN & B. vagans & 0 & 2 & 2 \\
\hline B7 & Canada & $\mathrm{BC}$ & 6.1 .5 & ALCAN & B. vagans & 4 & 1 & 5 \\
\hline B8 & Canada & YT & 6.1 .5 & ALCAN & B. centralis & 2 & 0 & 2 \\
\hline B8 & Canada & YT & 6.1 .5 & ALCAN & B. fernaldae & 4 & 0 & 4 \\
\hline B8 & Canada & YT & 6.1 .5 & ALCAN & B. insularis & 1 & 0 & 1 \\
\hline B8 & Canada & YT & 6.1 .5 & ALCAN & B. occidentalis & 3 & 0 & 3 \\
\hline B9 & Canada & YT & 6.1 .5 & ALCAN & B. occidentalis & 0 & 1 & 1 \\
\hline B10 & Canada & YT & 6.1 .5 & ALCAN & B. centralis & 1 & 0 & 1 \\
\hline B10 & Canada & YT & 6.1 .5 & ALCAN & B. occidentalis & 4 & 0 & 4 \\
\hline B11 & Canada & YT & 6.1 .5 & ALCAN & B. occidentalis & 4 & 0 & 4 \\
\hline B12 & Canada & YT & 6.1 .5 & Haines & B. bifarius & 0 & 1 & 1 \\
\hline B12 & Canada & YT & 6.1 .5 & Haines & B. fernaldae & 1 & 0 & 1 \\
\hline B12 & Canada & YT & 6.1 .5 & Haines & B. flavifrons & 1 & 1 & 2 \\
\hline B12 & Canada & YT & 6.1 .5 & Haines & B. insularis & 0 & 1 & 1 \\
\hline B12 & Canada & YT & 6.1 .5 & Haines & B. mixtus & 1 & 0 & 1 \\
\hline B12 & Canada & YT & 6.1 .5 & Haines & B. moderatus & 1 & 0 & 1 \\
\hline B12 & Canada & YT & 6.1 .5 & Haines & B. occidentalis & 1 & 5 & 6 \\
\hline B12 & Canada & YT & 6.1 .5 & Haines & B. rufocinctus & 0 & 1 & 1 \\
\hline B13 & Canada & YT & 6.1 .5 & Haines & B. bifarius & 0 & 1 & 1 \\
\hline B13 & Canada & YT & 6.1 .5 & Haines & B. fernaldae & 1 & 0 & 1 \\
\hline B13 & Canada & YT & 6.1 .5 & Haines & B. flavifrons & 0 & 2 & 2 \\
\hline B13 & Canada & YT & 6.1 .5 & Haines & B. moderatus & 2 & 0 & 2 \\
\hline B13 & Canada & YT & 6.1 .5 & Haines & B. occidentalis & 1 & 3 & 4 \\
\hline B14 & USA & $\mathrm{AK}$ & 7.1 .4 & Haines & B. flavifrons & 0 & 1 & 1 \\
\hline B14 & USA & $\mathrm{AK}$ & 7.1 .4 & Haines & B. mixtus & 2 & 3 & 5 \\
\hline B14 & USA & $\mathrm{AK}$ & 7.1 .4 & Haines & B. occidentalis & 3 & 5 & 8 \\
\hline B15 & Canada & $\mathrm{BC}$ & 6.2 .2 & $\mathrm{YH}$ & B. flavifrons & 1 & 0 & 1 \\
\hline B16 & Canada & $\mathrm{BC}$ & 6.2 .2 & YH & B. rufocinctus & 2 & 0 & 2 \\
\hline B16 & Canada & $\mathrm{BC}$ & 6.2 .2 & YH & B. vagans & 5 & 0 & 5 \\
\hline B17 & Canada & $\mathrm{BC}$ & 6.2 .2 & YH & B. bifarius & 3 & 0 & 3 \\
\hline B17 & Canada & $\mathrm{BC}$ & 6.2 .2 & YH & B. suckleyi & 1 & 0 & 1 \\
\hline B17 & Canada & $\mathrm{BC}$ & 6.2 .2 & YH & B. vagans & 1 & 0 & 1 \\
\hline B18 & Canada & $\mathrm{BC}$ & 6.2 .1 & YH & B. bifarius & 6 & 0 & 6 \\
\hline B18 & Canada & $\mathrm{BC}$ & 6.2 .1 & YH & B. vagans & 2 & 0 & 2 \\
\hline B19 & Canada & $\mathrm{BC}$ & 10.1 .1 & 97 & B. rufocinctus & 11 & 1 & 12 \\
\hline B19 & Canada & $\mathrm{BC}$ & 10.1 .1 & 97 & B. suckleyi & 2 & 0 & 2 \\
\hline B19 & Canada & $\mathrm{BC}$ & 10.1 .1 & 97 & B. vagans & 13 & 0 & 13 \\
\hline B20 & Canada & $\mathrm{BC}$ & 10.1 .1 & 97 & B. vagans & 5 & 12 & 17 \\
\hline TOTAL & & & & & & 118 & 88 & 206 \\
\hline
\end{tabular}

$\mathrm{a} \mathrm{AB}=$ Alberta, $\mathrm{BC}=$ British Columbia, $\mathrm{YT}=$ Yukon, $\mathrm{AK}=$ Alaska

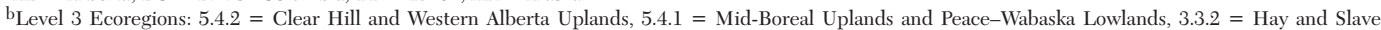
River Lowlands, 6.1.5 = Watson Highlands, 7.1.4 = Pacific Coastal Mountains, 6.2.2 = Chilcotin Ranges and Fraser Plateau, 6.2.1 = Skeena-Omineca-Central Canadian Rocky Mountains, 10.1.1 = Thompson-Okanagen Plateau

cALCAN = Alaska-Canadian Highway, YH = Yellowhead Highway 


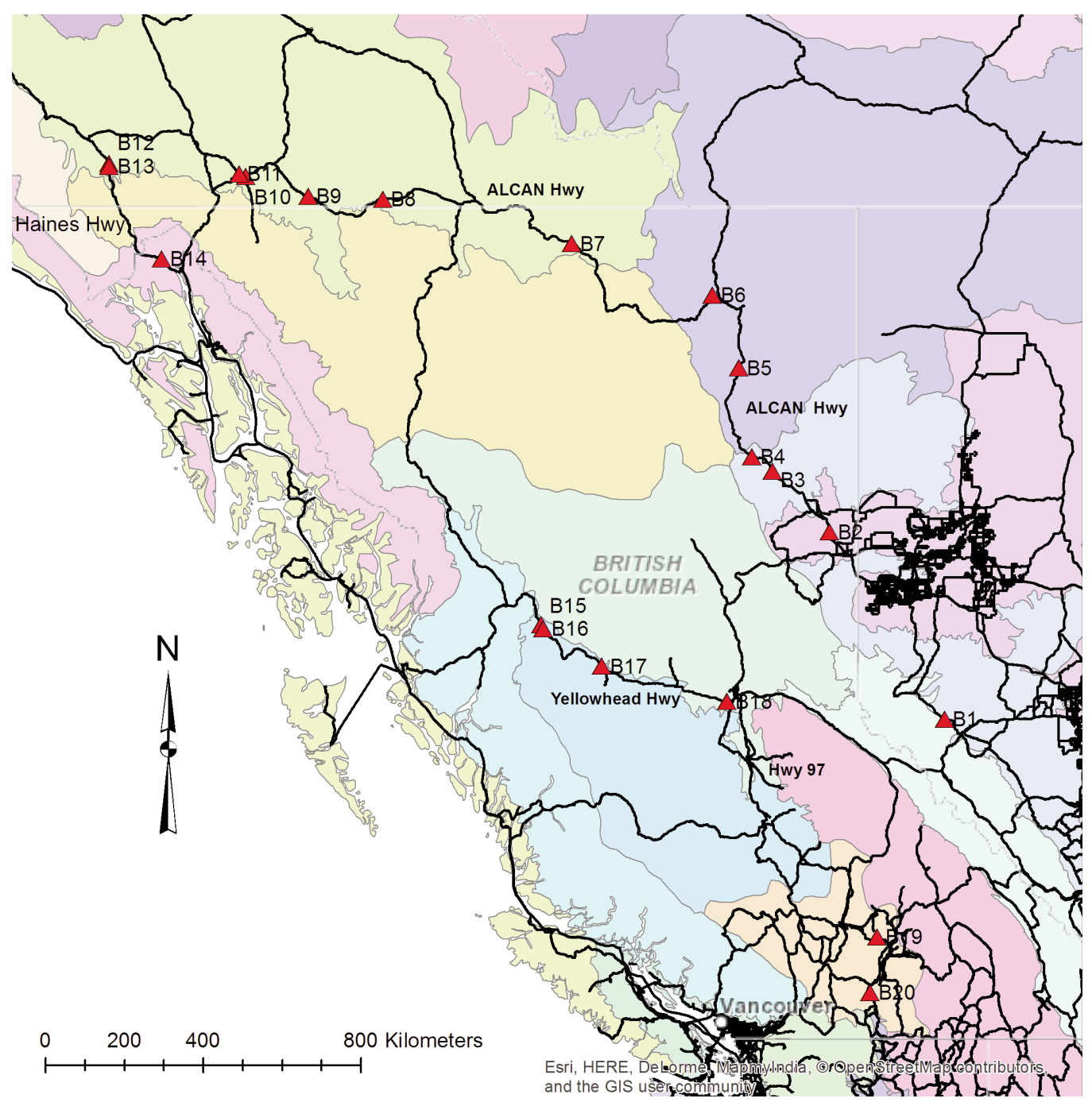

Fig. 2. Bumble bee sampling sites by Commission for Environmental Cooperation Level III Ecoregions along the 5 sampled highways; Highway 41, Alaska-Canadian Highway, Haines, Yellowhead, and Highway 97. Here: 5.4.2 = Clear Hill and Western Alberta Uplands; 5.4.1 = Mid-Boreal Uplands and Peace-Wabaska Lowlands; 3.3.2 = Hay and Slave River Lowlands; 6.1.5 = Watson Highlands; 7.1.4 = Pacific Coastal Mountains; 6.2.2 $=$ Chilcotin Ranges and Fraser Plateau; 6.2.1 = Skeena-Omineca-Central Canadian Rocky Mountains; and 10.1.1 $=$ Thompson-Okanagen Plateau.

Ranges and Fraser Plateau (ER6.2.2), and 1 within the Pacific Coastal Mountains (ER7.1.4) (Table 1, Fig. 2). These ecoregions are defined by the CEC as having distinct biological, physical, and human factors (Wiken et al. 2011). We incorporated these ecoregions into our analysis because the highways, in themselves, provide no ecological context for understanding observed faunal patterns.

At each sample site we sampled for approximately $30 \mathrm{~min}$, with 1-3 collectors per site, and each collector contributed to roughly 30 min (3 samplers $=10 \mathrm{~min} /$ collector, 2 samplers $=15 \mathrm{~min} /$ collector, etc.). We collected by sweep-netting bees (i.e., targeting them, using polyester nets with $45.7-\mathrm{cm}$ [18-inch] handles and 30.5-cm [12-inch] rings) on flowers in floral patches adjacent to each highway, with size of sampling areas ranging from 69.7 $\mathrm{m}^{2}\left(750 \mathrm{ft}^{2}\right)$ to $92.9 \mathrm{~m}^{2}$ (1000 $\left.\mathrm{ft}^{2}\right)$, depending on the roadside and habitat encountered. We sampled under a range of conditions from 9:00 
TABLE 2. Summary of principal component analysis.

\begin{tabular}{lccccc}
\hline Axes & 1 & 2 & 3 & 4 & Total variance \\
\hline Eigenvalues & 0.319 & 0.179 & 0.144 & 0.112 & 1 \\
Species-environment correlations & 0.916 & 0.575 & 0.548 & 0.434 & \\
Cumulative \% variance of species data & 31.9 & 49.9 & 64.3 & 75.5 & \\
Cumulative \% of species-environment data & 64.5 & 78.8 & 89.2 & 94.3 & 1 \\
Sum of all eigenvalues & & & & & 0.415 \\
Sum of all canonical eigenvalues & & & & & \\
\hline
\end{tabular}

to 19:00, but bees were only found across a temperature range of $8.3^{\circ} \mathrm{C}\left(47^{\circ} \mathrm{F}\right)$ to $19.4{ }^{\circ} \mathrm{C}$ $\left(67^{\circ} \mathrm{F}\right)$.

Captured bees were killed immediately and pinned within hours of collection or stored in $70 \%$ ethanol and pinned at a later time. Those that we stored in ethanol were cleaned and air dried with hair driers or the car heater vent and then pinned. Bees were identified and sexed at Invertebrate Ecology Inc. and the USDA-ARS Pollinating Insect Research Unit Lab in Logan, Utah.

Sample site data was recorded with a handheld global positioning system (Garmin eTrex Legend ${ }^{\circledR}$, <30 m resolution) and visualized using ArcMap 10.1 (ESRI 2012). Species abundances and composition were recorded, and the data were subsequently log transformed $(\mathrm{LN}(\mathrm{X}+1))$ to conform to the assumptions of normality. The species abundance and composition data, with a corresponding underlying environmental matrix comprised of latitude, longitude coordinates, and elevations per site, were analyzed with principal component analysis (PCA) in CANOCO 4.5 (ter Braak and Smilauer 2002). We constructed a species-site-environment triplot in CanoDraw 4.5 (ter Braak and Smilauer 2002 ) to show species optimas (maximal occurrence) relative to sample sites and correlation of the environmental variables with principal components. We also constructed a species-site biplot employing the use of site envelopes with CanoDraw 4.5. In such plots, sites linked by similar envelopes show sites found in the same ecoregion, whereas overlap of envelopes is indicative of shared species between ecoregions.

\section{RESULTS}

The flowering vegetation encountered in our sites was dominated by clover (Trifolium spp.) and other legumes, fireweed (Chamerion angustifolium), yarrow (Achillea millefolium), and occasionally goldenrod (Solidago sp.). Along the Haines Highway we observed a greater proportion of dandelion (Taraxacum sp.) in the ubiquitous clover but little fireweed. The same observation was made for the Yellowhead Highway and Highway 97, while Highway 97 also had a component of aster (Symphyotrichum spp.).

A total of 206 bumble bees representing 14 species were collected from the 20 sample sites (Table 1, Fig. 1). The 7 most abundant species made up $86.4 \%$ of all captures (Table 1), listed here in order of descending abundance: $B$. (Pyrobombus) vagans, B. (Collumanobombus) rufocinctus, B. occidentalis, B. (Pyrobombus) flavifrons, B. terricola, B. (Pyrobombus) bifarius and Bombus moderatus. The 7 most common species based on percentage of sites with detections were B. vagans (45\%, e.g., 9/20 sites), B. occidentalis $(35 \%)$, B. flavifrons (35\%), B. rufocinctus $(25 \%)$, B. bifarius $(20 \%)$, and B. terricola $(20 \%)$. Male bees made up $57.3 \%$ of all captures and were present in all sites except 2 (Table 1).

As shown in Table 2 , axis 1 of the PCA explained $31.9 \%$ of species variance, axis 2 explained an additional $17.9 \%$, and axes 3 and 4 explained $>10 \%$ of species variance apiece for a total of $75.4 \%$ by these 4 axes. Axes were strongly correlated with the linear combination of environmental variable scores (i.e., latitude, longitude, and elevation), e.g., $r=0.92$ for axis $1, r=0.58$ for axis $2, r=0.55$ for axis 3 , and then decreases for axis 4 and beyond. For axis 1, longitude and latitude were almost equally correlated $(r=0.80$ for longitude ["Easting"], $r=-0.79$ for latitude ["Northing"], but for axes 2 and 3 longitude was more strongly correlated than latitude. In contrast, elevation was the most strongly correlated variable with axes 2 and $3(r=0.47$ and $r=0.40$, respectively). In total, canonical eigenvalues accounted for $41.5 \%$ of the species variance (Table 2 ).

Ordination plots showing species relationships to axes 1 and 2 and latitude, longitude, 

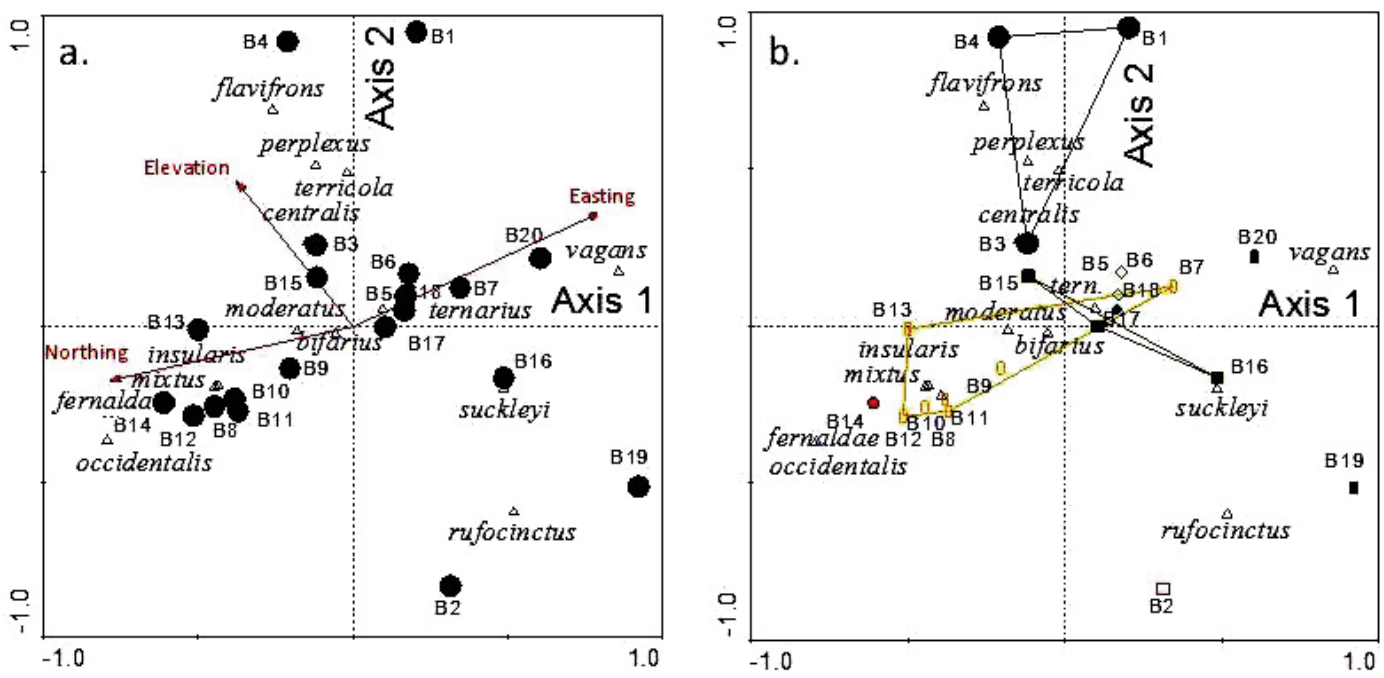

Fig 3. Bumble bee species-site-environment triplot (a) and species-site biplot (b), the latter with envelopes delineating sites encompassed by each ecoregion (only those with $>2$ sites delineated; those with $<3$ designated by symbol). Envelopes: Black circle = Clear Hills and Western Alberta Upland ecoregion; clear yellow = Watson Highlands ecoregion; filled square $=$ Chilcotin Ranges and Fraser Plateau ecoregion.

and elevation are presented in Figure $3 \mathrm{a}$, and to axes 1 and 2 and ecoregions coded with site envelopes and symbols in Figure 3b. Strong patterns are evident in these plots and are readily verifiable with data shown in Table 1 . For example, B. occidentalis was placed in the lower left quadrant distad to the northing vector, but also opposite of the easting vector, correctly showing abundance of the species to have been greatest in the study area's northwestern sites. In contrast, B. vagans was placed in the opposite quadrant along the negative end of these vectors, indicating the opposite pattern. Bombus bifarius was positioned more intermediately, although still positively correlated with the north and west vectors. Bombus flavifrons, B. (Pyrobombus) perplexus, and $B$. terricola were also placed more along axis 2 , reflecting a stronger correlation with longitude and elevation than with latitude. In the case of equal or shared abundance among sites, placement of species in ordination space was intermediate or skewed between sites, as depicted by $B$. bifarius plotted just off the center of the plot, or $B$. flavifrons nearest sites $\mathrm{B} 1$ and $\mathrm{B} 4$, or B. rufocinctus between sites B2 and $\mathrm{B} 19$, but not by $B$. vagans because of its dominance in sites B19 and B20. The less abundant species, such as $B$. perplexus, $B$. (Pyrobombus) centralis, B. (Pyrobombus) ter- narius, B. (Pyrobombus) mixtus, B. moderatus, and B. (Psithyrus) insularis were also accurately plotted.

These data, shown in Figure 3b but with site envelopes, revealed separation and overlap in Bombus assemblages by ecoregion. Sites located in the Clear Hills and Western AB Upland separated out in the upper quadrants of the plot, and those of the Watson Plateau separated primarily into the lower-left quadrant, while sites of the Chilcotin Ranges and Fraser Plateau ecoregion extended through the center of the plot and overlapped with the Watson Plateau. Those ecoregions with $<3$ sites were not linked by envelopes but they were coded by symbols, and it can be seen that sites B19 and B20 of the ThompsonOkanagan Plateau ecoregion occupied the farright side of the plot while B14 of the Pacific Coast Mountains ecoregion occupied the left side of the lower-left quadrant, and SkeenaOmineca-Central Canadian Rocky Mountains occupied the center, revealing segregation or separation of communities among ecoregions.

\section{Discussion}

We found that males were more common than females during the study $(57.3 \%$ to $42.7 \%$, respectively), a result underscoring the 
waning summer season in which we sampled; males are produced near the end of the season to mate with gynes (Goulson 2010), and high male-to-female ratios in our sites are indicative that colonies had run their course. Clearly, gender ratios, abundance, and speciesrichness patterns would change if a similar survey were performed earlier in the season or over multiple sample dates-an exciting prospect for future efforts.

Our late-season snapshot survey detected 2 of the 4 bumble bee species that have been declining in the United States, B. terricola and B. occidentalis. This result provided support for our hypothesis concerning the occurrence of $B$. occidentalis in Canada adjacent to AK. The other 2 species, B. franklini and B. affinis, were neither detected nor expected: $B$. franklini is endemic to the Klamath Mountains of southern Oregon and northern California and B. affinis is an eastern North American species (Williams et al. 2014). Our finding of B. terricola in BC provides important new distribution data for this eastern species whose populations in the southern and eastern portions of its geographic range have been in decline (Cameron et al. 2011). We detected B. terricola along the ALCAN from approximately road km 180 to road km 400 in the Peace River Regional District of BC. Hobbs (1968) provides records of $B$. terricola from the northern regions of $\mathrm{AB}$, stating that it was the most common bumble bee found in the Peace River region, but his investigations did not extend into BC.

The B. terricola collection sites were in the forested habitat along the foothills of the Muskwa Mountains on the east side of the Continental Divide. Preferred habitat for the species is near or within wooded areas and wetlands (Williams et al. 2014). Published historical records show only a couple of collections for the species in $\mathrm{BC}$, and these fall within this same general area (Milliron 1971). Our B. terricola collection sites occurred within the Clear Hills and Western AB Upland of the Boreal Plain and the Hay and Slave River Lowlands of the Taiga-Plain ecosystems. As both ecoregions extend eastward for hundreds of miles, one can assume a level of habitat connectivity and environmental suitability for $B$. terricola given its presence in BC.

The relatively high numbers of $B$. occidentalis from our most northern sites indicate that the species is not rare along the YT-BC border region of the ALCAN (approximately 60 ${ }^{\circ} \mathrm{N}$ ) nor along the Haines Highway from Haines Junction to Haines, AK. We found $B$. occidentalis to be present in $88 \%$ of these sites and to comprise $51.7 \%$ of all captures. Historical records for the species showed it to be well distributed and abundant in this northern area (Milliron 1971). This finding parallels that of Koch and Strange (2012), who found B. occidentalis to be common in $\mathrm{AK}$, a distance of approximately 1000 to $2400 \mathrm{~km}$ to the westnorthwest of the BC-YT border sites.

We did not encounter B. occidentalis until the ALCAN had crossed over the Continental Divide in the Northern Rocky Mountains. The species is predominantly western, and all our sample sites prior to this point were from east of the Rocky Mountains. Preferred habitat for the species is open areas, chaparral and shrub, and mountain meadows (Williams et al. 2014). Milliron's (1971, p. 64) records indicate it to have been distributed as far west as Watson Lake and as far north as Dawson, YT, the latter some $1000 \mathrm{~km}$ to the northwest in the Watson Plateau ecoregion. The Watson Plateau grades into other ecoregions of the Boreal Cordillera and the AK Boreal Interior where B. occidentalis was recently detected (Koch and Strange 2012).

Bombus occidentalis populations found along the Haines Highway were also located in the Watson Plateau with the exception of the last sample that was situated in the Pacific Coast Mountains ecoregion of AK. The latter sample fell within the Closed Forest vegetation zone (Wiken et al. 2011), and B. occidentalis comprised $>50 \%$ of the catch. While there are ample records for the species in mainland AK, we could find but a couple dozen from southeast AK (Milliron 1971, p. 65; Global Biodiversity Information Facility 2015), and these were all located within the same vicinity as the current sites.

The putative causal agent for the decline of B. (Bombus) species in southern BC and the United States is infection by the intracellular pathogen N. bombi (Cameron et al. 2011). Pathogen status was not assessed in the current study; thus, its status in our YT populations remains unknown. Koch and Strange (2012) were perplexed by their finding of high $N$. bombi infection rates in Alaska populations of $B$. occidentalis because they found 
this bumble bee to be very common throughout AK. Bombus (B.) populations in AK are relatively isolated from commercially reared bumble bees, which are believed to have spread N. bombi to wild populations, prompting the authors to speculate that infection levels in AK might reflect natural host-pathogen dynamics rather than a recent infection (Koch and Strange 2012).

In addition to the 2 declining $B$. (Bombus) species, we captured 12 other bumble bee species for a total of 14 species or $34 \%$ of the Canadian Bombus fauna (NRC 2007). Of these, there were distinct Bombus assemblages associated with $B$. occidentalis and B. terricola, with $<50 \%$ of species shared among communities. Our PCA plots presented in Fig. 3 show these assemblages and indicate that there was a strong structuring effect of geography on the bees. Biogeographers have known about latitudinal and longitudinal species gradients for over a century (Brown and Gibson 1983). Nonetheless, it is important to document species ranges and to gather spatially explicit baseline data for habitat and climate modeling purposes. Lack of existing data to establish the status of B. (Bombus) species in BC and YT (Koch and Strange 2012) underscores this point and provided the impetus for our snapshot survey.

Terrain also plays an important role in the biogeography of species distributions (Brown and Gibson 1983). Clearly, the Rocky Mountains are a dramatic example of terrain, a feature that affected survey results. These mountains largely delimit the longitudinal extent of many species such as the 2 detected $B$. (Bombus) species and other Bombus as well (Williams et al. 2014). The longitudinal species gradients shown in Figure 3 are confounded by the Rocky Mountains, which bisect the area in a southeast to northwest manner. Nevertheless, our survey detected relatively distinct species assemblages from east to west in the area. The elevational species gradient detected in the PCA is also a function of terrain because east-side Rocky Mountain sites were situated at higher elevations $(\bar{x}=1180 \mathrm{~m})$ than were west-side sites $(\bar{x}=811 \mathrm{~m})$, including the Haines Highway sites $(\bar{x}=800 \mathrm{~m})$.

Ecoregions provided ecological context for our findings, albeit their effectiveness for discerning Bombus patterns remains unclear. For some species, patterns within and among sites by ecoregion were more readily dis- cernible and explicable than when analyzed by highway alone. For example, although multiple B. (Bombus) specimens were collected along the ALCAN Highway, B. occidentalis was found primarily within the Watson Plateau, whereas B. terricola was found only in the Clear Hills and Western AB Upland and Hay and Slave River Lowlands ecoregions. Bombus (Bombus)-associated species, comprising an assemblage, were also discernibly grouped by ecoregion, as were Bombus in the most southern ecoregion, the Thompson-Okanagen Plateau.

In contrast, clear ecoregional patterns were not always evident in our analysis because some species (e.g., B. bifarius, B. rufocinctus, $B$. flavifrons, and B. vagans, etc.) were detected across multiple ecoregions. This is not surprising given that many Bombus species are broadly distributed. Ecoregions are comprised of a complex of ecosystems, each containing a diversity of plant communities structured by an array of biological and physical factors (Wiken et al. 2011), capable of supporting Bombus occurrence. Similar component ecosystems among ecoregions could be expected to support similar (or the same) Bombus species. A more intensive survey is needed to adequately assess ecoregional patterns of bumble bees in the study area.

Ecoregional factors influence the species assemblages that utilize roadside habitats, whereas proximal factors determine degree of usage within them. Vegetation management practices that affect plant communities also affect the biota dependent on them (Noordijk et al. 2009). Both in BC and YT, roadsides are mowed to control weeds and vegetation, to improve drainage, and to maximize visibility by highway users (British Columbia Ministry of Transportation 2003). Herbicides are also applied but only to control noxious weeds (British Columbia Ministry of Transportation 2009). The dates of highway maintenance differ by highway and section, and maintenance records for 2010 were accurate only to within 1-2 months. These records indicate that some, and perhaps all, highway roadsides had received 1 or 2 mowings by the time of our study. Clearly, such practices must affect the bee fauna, but we are unaware of any studies conducted on the topic for the study area, and an examination of treatment effects was beyond the scope of this study. Only dominant flowering taxa along highway sections were 
noted by us, and these were highly visible, late-flowering species-e.g., clover, goldenrod, fireweed, asters, etc.-with small-statured individuals (e.g., clover and dandelion) found closest to the roadsides and tall-statured ones found along the outer perimeter (e.g., goldenrod and fireweed). Each of these is attractive to bees; goldenrod in particular is a valuable nectar and pollen source, and asters are regarded as an important, late-season food source for bumble bees (Mader et al. 2011).

In AK, Armbruster and Guinn (1989) found that roadside habitats resembled early successional habitats that provide floral resources, well-drained nesting sites, and favorable conditions for sun-basking. Their study focused primarily on exothermic solitary bees, whose environmental requirements differ somewhat from bumble bees, but they sampled across multiple sample dates and recorded bumble bee occurrence (generic level) across many habitat types including roadsides (Armbruster and Guinn 1989, p. 475). The roadsides we sampled also tended to be open, relatively xeric, and frequented by bees. It is unknown whether our bumble bees were nesting in the roadsides, foraging exclusively or differently within them, or whether the observed fauna differed from that of adjoining habitats. Additional studies will be required to investigate such questions.

In conclusion, the results of our snapshot survey indicate that $B$. occidentalis and B. terricola were relatively common along the ALCAN Highway and were segregated west and east by the Rocky Mountains, respectively, via relatively well-established distribution patterns for these species. Variability of the broader bumble bee community was structured in part by latitude, longitude, and elevation, and Level III Ecoregions helped to interpret community patterns within and among sampled highways. An early- to midseason study could yield important complementary data on bumble bee communities found along the region's highways. A study on the conservation benefits of roadside management practices for these communities might also be warranted.

\section{ACKNOWLEDGMENTS}

We thank Rhea Hatten and Shay Hatten for their assistance with field sampling and pinning.

\section{Literature Cited}

Armbruster, W.S., AND D.A. GuINn. 1989. The solitary bee fauna (Hymenoptera: Apoidea) of interior and Arctic Alaska: flower associations, habitat use, and phenology. Journal of the Kansas Entomological Society 62:468-483.

Bishop, J.A., AND W.S. ARmbruster. 1999. Thermoregulatory abilities of Alaskan bees: effects of size, phylogeny and ecology. Functional Ecology 13:711-724.

British Columbia Ministry of Transportation. 2003. Maintenance Specifications, 10-30-2003.

2009. Use of herbicides for invasive plant control. Technical Circular T-08/09.

Brown, J.H., AND A.C. GiBson. 1983. Biogeography. Mosby, St. Louis, MO.

Cameron, S.A., J.D. Lozier, J.P. Strange, J.B. Koch, N. Cordes, L.F. Solter, And T.L. Griswold. 2011. Patterns of widespread decline in North American bumble bees. Proceedings of the National Academy of Sciences of the United States of America 108: 662-667.

Colla, S.R., And L. Packer. 2008. Evidence for decline in eastern North American bumblebees (Hymenoptera: Apidae), with special focus on Bombus affinis Cresson. Biodiversity Conservation 17:1379-1391.

Colla, S.R., and C.M. RatTi. 2010. Evidence for the decline of the western bumble bee (Bombus occidentalis Greene) in British Columbia. Pan-Pacific Entomologist 86:32-34.

Cordes, N., W.-F. Huang, J.P. Strange, S.A. Cameron, T.L. Griswold, J.D. LOZIER, AND L.F. SOlter. 2012. Interspecific geographic distribution and variation of the pathogens Nosema bombi and Crithidia species in United States bumble bee populations. Journal of Invertebrate Pathology 109:209-216.

ESRI. 2012. ArcGIS Desktop: Release 10.1. Environmental Systems Research Institute, Redlands, CA.

GLOBAL BIODIVERSITY INFORMATION FACILITY. 2015. Bombus occidentalis Greene, 1858 [web application]. [Accessed 15 Feb 2015]. http://www.gbif.org/species/1340429

Goulson, D. 2010. Bumblebees: behavior, ecology and conservation. Oxford University Press, Oxford, United Kingdom.

Goulson, D., G.C. Lye, and B. Darvill. 2008. Decline and conservation of bumble bees. Annual Review of Entomology 53:191-208.

Hoвbs, G.A. 1968. Ecology of species of Bombus (Hymenoptera: Apidae) in southern Alberta. VII. Subgenus Bombus. Canadian Entomologist 100:156-164.

Kearns, C.A., And J.D. Thomson. 2001. The natural history of bumble bees: a sourcebook for investigations. University Press of Colorado, Boulder, CO.

Koch, J.B., and J.P. Strange. 2012. The status of Bombus occidentalis and B. moderatus in Alaska with special focus on Nosema bombi incidence. Northwest Science 86:212-220.

Lentini, P.E., J. Fischer, P. Gibbons, D.B. Lindenmayer, and T.G. Martin. 2011. Australia's Stock Route Network: 1. A review of its values, and implications for future management. Ecological Management and Restoration 12:119-127.

Mader, E., M. Shepherd, S.H. Black, and G. Lebuhn. 2011. Attracting native pollinators. Protecting North America's bees and butterflies. Storey Publishing, North Adams, MA. 
Milliron, H.E. 1971. A monograph of the western hemisphere bumblebees (Hymenoptera: Apidae; Bombinae) I. The genera Bombus and Megabombus subgenus Bombias. Memoirs of the Entomological Society of Canada 82:iii-80.

Munguira, M.L., And J.A. Thomas. 1992. Use of road verges by butterfly and burnet populations, and the effect of roads on adult dispersal and mortality. Journal of Applied Ecology 29:316-329.

[NRC] National Research Council. 2007. Status of pollinators in North America. National Academies Press, Washington, DC.

Noordijk, J., K. Delille, A.P. Schaffers, and K.V. SYKORA. 2009. Optimizing grassland management for flower-visiting insects in roadside verges. Biological Conservation 142:2097-2103.

Ries, L., D.M. Debinski, AND M.L. Wieland. 2001. Conservation value of roadside prairie restoration to butterfly communities. Conservation Biology 15: 401-411.

Saarinen, K., A. Valtonen, J. Jantunen, and S. SaArnio. 2005. Butterflies and diurnal moths along road verges: does road type affect diversity and abundance? Biological Conservation 123:403-412. ter Braak, C.J.F., and P. Smilauer. 2002. CANOCO reference manual and CanoDraw for Window's user's guide: software for canonical community ordination, version 4.5. Microcomputer Power, Ithaca, NY.

Thomson, D. 2004. Competitive interactions between the invasive European honey bee and native bumble bees. Ecology 85:458-470.

Thorp, R.W., and M.D. Shepherd. 2005. Profile: subgenus Bombus. In: M.D. Shepherd, D.M. Vaughan, and S.H. Black, editors, Red list of pollinator insects of North America. CD-ROM Version 1. The Xerces Society for Invertebrate Conservation, Portland, OR.

Wiken, E., F.J. Nava, and G. GRIffith. 2011. North American terrestrial ecoregions-level III. Commission for Environmental Cooperation, Montreal, Canada.

Williams, P.H., R.W. Thorp, L.L. Richardson, and S.R. Colla. 2014. Bumble bees of North America. Princeton University Press, Princeton, NJ.

Received 23 July 2014 Accepted 7 March 2015 